\title{
PERKEMBANGAN DAN INTERAKSI MODAL EKSPATRIAT BERBASIS TOURISM AREA LIFE CYCLE DI UBUD
}

\author{
Nararya Narottama \\ Fakultas Pariwisata Universitas Udayana \\ Email: nararya.narottama@unud.ac.id \\ Natasha Erinda Putri Moniaga \\ Fakultas Pariwisata Universitas Udayana \\ Email: erindaputri19@unud.ac.id
}

\begin{abstract}
The expatriates in Ubud have played an important role in the development of Balinese tourism since the early 20th century and their influence continues today. This study aims to examine the development, dynamics and interactions of capitals between expatriates, society and local elites by adapting the Tourism Area Life Cycle (TALC) model, combined with Bourdieu's capital theory and Homan's social exchange theory as an analytical tool. This qualitative research uses critical phenomenological analysis based on action research, with data collection methods in the form of participatory observation, in-depth interviews and documentation studies, with research locus in Ubud and its surroundings. This research is intended to assist stakeholders, practitioners and tourism academics in uncovering the development and interaction of expatriate capital that occurs in the realm of Ubud based on the life cycle of tourism destinations. This research reveals that by adapting the TALC model, currently the development of Ubud tourism is at a consolidation stage, and the interaction of capitals (economic capital, cultural capital, symbolic capital and social capital) is becoming tighter and more complex. In all these processes, the symbiosis of mutualism is more dominant, although in some cases there are still practices of marginalization and hegemony which are measured based on ownership of capital.
\end{abstract}

Keywords: expatriate, development, capital, tourism area life cycle 


\section{Pendahuluan}

Sejak awal abad ke-20, perkembangan industri pariwisata Bali tidak terlepas dari peran ekspatriat di Ubud. Pasca perang dunia (periode 1920 hingga 1930-an), desa Ubud dan sekitarnya semakin ramai dikunjungi oleh para seniman, antropolog, dan penulis asing. Mereka kemudian memilih untuk menetap dan berkarya di Ubud, sebagai imigran internasional yang populer disebut ekspatriat (expatriate). Sebagai sebuah istilah, 'ekspatriat' dapat mengacu pada suatu benua, bangsa ataupun etnis, tergantung dari asal/akar geografis pelakunya.

Salah seorang ekspatriat yang memiliki nama besar di Bali adalah Walter Spies, seniman multi talenta asal Jerman yang datang ke Bali pada era tahun 1927 atas undangan Raja Ubud - (Alm) Tjokorda Gede Raka Sukawati. Pada tahun 1930, Walter Spies bersama seniman lokal bernama I Wayan Limbak, menggubah dan berhasil mempopulerkan Tari Kecak di seluruh dunia. Ada pula Rudolf Bonnet, seorang seniman Belanda kelahiran tahun 1895 yang datang ke Bali pada tahun 1929. Spies dan Bonnet kemudian memperkenalkan teknik estetika Eropa kepada para seniman lokal Ubud, yang dipadukan dengan identitas tradisional dan gaya setempat, yang melahirkan gaya lukis khas Ubud atau Ubud style (Pitanatri dan Putra, 2016:17).

Sejak berinteraksi dengan ekspatriat (beserta modal ekonomi, modal sosial, modal simbolis, dan modal budaya yang melekat padanya- Bourdieu, 2007:106), masyarakat Bali mengalami perubahan ideologis. Hal ini sejalan dengan perkembangan pariwisata dan semakin maraknya wisatawan, peneliti, musisi, pengusaha dan penulis asing yang datang ke Ubud pada periode waktu berikutnya. Secara perlahan, orientasi ideologi masyarakat Bali yang menganggap aktifitas seni, budaya dan keramahtamahan sebagai wujud spiritualisme murni yang tulus, mulai beralih ke orientasi ekonomis dalam nuansa kapitalisme modern yang kental nan kosmopolis. Proses ini tidak terjadi secara instan, namun berjalan seiring perkembangan destinasi tersebut. Demikian pula dengan bentuk interaksi modal 
yang terjadi dalam relasi antara ekspatriat, masyarakat lokal dan pariwisata. Penelitian menjadi penting, mengingat bahwa perkembangan pariwisata Bali dan Ubud saat ini tidak terlepas dari dinamika interaksi modal yang terjadi antara para elit, masyarakat lokal dan ekspatriat yang menetap di Ubud sejak lama. Selain itu, diharapkan penelitian ini bisa menjelaskan implikasi, dampak dan makna atas perkembangan ekspatriat dan interaksi modal mereka berdasarkan siklus hidup destinasi wisata di Ubud.

Berdasarkan pemaparan di atas, rumusan masalah dalam penelitian ini adalah: Bagaimanakah perkembangan dan interaksi modal ekspatriat berbasis Tourism Area Life Cycle di Ubud? Melalui penelitian ini, diperoleh gambaran mengenai perkembangan dan interaksi modal ekspatriat di destinasi wisata yang bisa dipakai sebagai acuan dalam penyusunan rekomendasi bagi berbagai permasalahan yang terjadi terkait dunia pariwisata, sosial-budaya, masyarakat lokal dan keberadaan ekspatriat di Bali dan Indonesia secara umum. Untuk menjelaskan perkembangan destinasi, salah satu alat analisis yang bida digunakan adalah teori siklus hidup destinasi wisata atau Tourism Area Life Cycle (TALC), sedangkan untuk interaksi modal akan dijelaskan melalui pendekatan teori modal Bourdieu (1991) dan teori pertukaran sosial dari Homans (1958).

\section{Tinjauan Hasil Penelitian Sebelumnya}

Pada berbagai literatur barat, penelitian maupun kajian mengenai ekspatriat dan proses ekspatriasi telah banyak dilakukan (Armstrong, 1976; Butler, 2001; Cohen, 1997; Dufoix, 2008). Di Ubud, beberapa penelitian kontemporer mengenai ekspatriat (MacRae, 2014; Green, 2016) dan wisatawan hippies (Ningtyas, 2016) telah memberikan justifikasi sekaligus informasi mendasar mengenai keberadaan dan sepak terjang mereka. Berkat kehadiran ekspatriat (dalam konteks diaspora Eropa), kawasan Ubud 
mengalami perubahan sosial, budaya dan ekonomi yang pesat melalui pariwisata (Narottama, 2016).

Ekspatriat asing berkontribusi terhadap perkembangan pariwisata Bali, baik secara langsung maupun tidak langsung, dan kehadiran mereka memberikan implikasi yang besar bagi masyarakat Bali (Picard, 1992). Pada proses ini, berbagai elemen bercampur baur dan kawasan Ubud pada akhirnya terhubung dengan berbagai kutub kepentingan, dalam lingkup lokal, regional dan internasional (MacRae, 1997). Meskipun dinamika pariwisata di Ubud dianggap sebagai pematik terjadinya "renaisans kebudayaan" Bali (Picard, 1992), namun pada kenyataannya pariwisata adalah wujud kapitalisme yang menghegemoni dan menyebabkan masyarakat lokal Ubud harus menanggung beban ekonomis yang lebih tinggi karena pemeliharaan budaya atas nama pariwisata (Sudipa, 2014). Saat ini ada berbagai penelitian mengenai ekspatriat, namun sejauh pengetahuan penulis, belum ditemukan kajian yang secara khusus membahas mengenai perkembangan dan interaksi modal ekspatriat, terutama yang berbasis pada Tourism Area Life Cycle (TALC) di Ubud maupun di Bali.

\section{Metolodogi}

Penelitian ini menggunakan analisis fenomenologi kritis berbasis action research, dengan metode pengumpulan data berupa observasi partisipatif di lapangan, wawancara mendalam dengan para ekspatriat, tokoh dan masyarakat lokal Ubud yang terdiri dari 10 informan kunci dan 56 responden, beserta studi dokumentasi baik secara offline maupun online. Periode penelitian dilakukan antara tahun 2014-2018 dengan lokus penelitian berada di kawasan pariwisata Ubud dan sekitarnya. 


\section{Tourism Area Life Cycle (T.A.L.C.)}

Terinspirasi dari konsep pemasaran Product Life Cycle (P.L.C. - Siklus Hidup Produk, Levitt, 1965), Butler (1980) mengembangkan sebuah model untuk menjelaskan siklus hidup destinasi wisata yang dikenal dengan Tourism Area Life Cycle (T.A.L.C. - Siklus Hidup Kawasan Pariwisata). Butler meyakini bahwa sebuah destinasi pada dasarnya adalah produk yang memiliki pola-pola perkembangan dan siklus hidupnya sendiri.

Siklus Hidup Kawasan Pariwisata

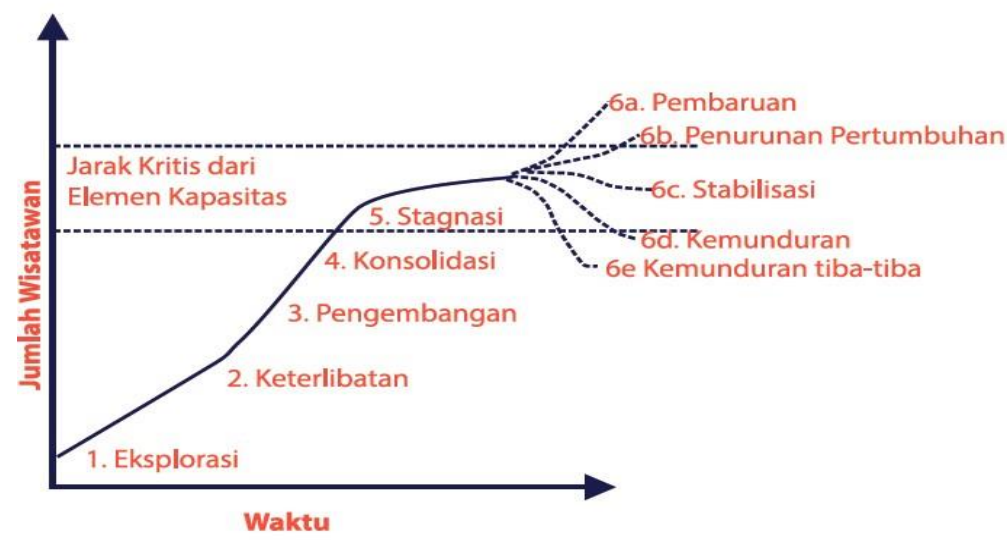

Gambar 1. Model Tourism Area Life Cycle (T.A.L.C) oleh Butler (1980)

Menurut Butler, sebuah destinasi memiliki lima tahapan perkembangan beserta kemungkinan-kemungkinan trend masa depan ketika tahapan terakhir tercapai, yakni (1) Tahap Eksplorasi - Exploration Stage, (2) Tahap Keterlibatan Involvement Stage, (3) Tahap Pengembangan - Development Stage, (4) Tahap Konsolidasi - Consolidation Stage, dan (5) Tahap Stagnasi - Stagnation Stage, di mana pada tahap ini ada dua kemungkinan trend, yakni terjadi penurunan (Decline) atau justru peremajaan (Rejuvination). Asumsi utamanya, semakin banyak pangunjung (dan seiring waktu) pada sebuah destinasi, maka ada penurunan kualitas dan daya tarik ketika batas kapasitasnya tercapai. Pada penelitian ini, model T.A.L.C. diadaptasi dalam konteks perkembangan dan interaksi modal yang terjadi pada masing-masing tahapan. 


\section{Teori Modal Bourdieu}

Untuk menjelaskan modal ekspatriat, penelitian ini menggunakan beberapa konsep penting dalam teori modal Bourdieu antara lain mengenai habitus, ranah (field), kekerasan simbolik (symbolic violence), modal (capital) dan strategi (strategy) (Siregar, 2016). Menurut Bourdieu (1991), ada berbagai bentuk modal, di antaranya :

1. Modal ekonomi (economic capital, berupa alat produksi dan kekayaan material seperti uang, properti, saham dll. Modal ini dapat diwariskan pada generasi selanjutnya).

2. Modal budaya (cultural capital, berupa akuisisi budaya dan keseluruhan kualifikasi intelektual, seperti kedalaman pengetahuan, keterampilan, keahlian, penguasaan bahasa, tingkat pendidikan, kompetensi teknis, dll).

3. Modal simbolik (symbolic capital, berupa akumulasi dari prestise, harga diri, status sosial, kehormatan, pengakuan, agama, otoritas, jabatan dll yang diraih secara jangka panjang, sekaligus sebagai simbol penting di masyarakat).

4. Modal sosial (social capital, berupa jaringan sosial yang dimiliki terutama hubungannya dengan pihak yang memiliki kuasa, seperti hubungan pertemanan, kekerabatan dll).

\section{Teori Pertukaran Sosial Homans}

Sedangkan untuk menjelaskan interaksi modal yang terjadi, penelitian ini menggunakan teori Pertukaran Sosial dari Homans (1958). Teori ini berangkat dari konsep social behaviorism, yang menggunakan prinsip-prinsip dari ilmu ekonomi (yakni law of utility 5aximization atau pemanfaatan penuh nilai guna dan law of diminishing marginal utility, untuk menjelaskan mengenai penurunan nilai guna atas penambahan konsumsi), teori psikologi yakni, behaviorism dan juga teori pilihan rasional. Homans meyakini bahwa individu terus menerus bekerja karena 
memperoleh imbalan (reward) dan berhenti melakukan sesuatu jika menimbulkan kerugian atau hukuman (loss or punishment) individual.

\section{Hasil dan Pembahasan}

Sejak awal abad ke 20, perkembangan dan interaksi modal antara ekspatriat, masyarakat dan elit Ubud terjadi secara dinamis, serta didominasi oleh simbiosis mutualisme di antara mereka. Untuk memperoleh gambaran yang lebih jelas mengenai dinamika yang terjadi pada kurun waktu tersebut, penelitian ini mengadaptasi model Tourism Area Life Cycle. Berdasarkan model ini, perkembangan dan interaksi modal ekspatriat dapat dijelaskan dalam beberapa tahapan, sebagai berikut:

\section{Tahap Eksplorasi (The Exploration Stage)}

Tahap Eksplorasi merupakan masa-masa awal kedatangan ekspatriat di Ubud pada periode tahun 1920 hingga 1950-an. Pasca Perang Puputan, pada tahun 1914 pemerintah Belanda membuka kantor biro perjalanan wisata (Vereeniging Touristenverkeer in Netherland Indie - Official Tourist Bureau) di Bali (Picard, 1992), serangkaian dengan kebijakan kolonial Belanda era Rafles, yakni Baliseering atau 'Balinisasi' yang memberi perhatian lebih pada seni dan budaya lokal, menganggap Bali 'istimewa namun rapuh', serta paling berpotensi untuk pengembangan pariwisata dibandingkan daerah jajahan lainnya.

Pada era 1930-an, Bali merupakan bagian dari jalur singgah kapal pesiar, wisatawan asing yang didominasi Eropa dan Amerika dapat berkeliling pulau dengan menggunakan bis atau mobil (Reader dan Ridout, 2002 : 202). Di awal masa ini, nama Ubud belum banyak dikenal orang. Selain para birokrat Belanda, jumlah ekspatriat yang datang ke Ubud masih sangat sedikit. Beberapa tokoh yang terkenal pada masa itu adalah Walter Spies (datang ke Ubud pada 1927 atas undangan Raja Ubud), Rudolf Bonnet (1929), Miguel Covarrubias (1930), Vicki Baum (1935), Gregory 
Bateseon dan Margaret Mead (1936) Romualdo Locatelli (1939), Han Snel dan Willem Hofker (1940), disusul oleh Auke Sonnega dan Arie Smit (1956). Melalui berbagai karyanya, para ekspatriat tersebut membentuk citra positif dan mengharumkan nama Bali di kancah internasional, terutama di Amerika dan Eropa. Pada periode ini, Ubud merupakan destinasi alternatif dari pariwisata Kuta yang dianggap terlalu liar. Berbeda dengan Kuta, atraksi utama bagi para wisatawan asing yang datang ke Ubud adalah melihat keindahan alam, menonton pertunjukan seni budaya di Puri Ubud, bertemu masyarakat lokal, membeli lukisan dan tentunya bertemu Walter Spies, seorang seniman flamboyan yang punya banyak relasi.

Miguel Covarrubias (1937), ekspatriat yang datang karena terinspirasi Gregor Krause, menyebut bahwa Walter Spies adalah seniman yang paling terkenal ketika itu, seorang yang dianggap ahlinya Bali, sekaligus sebagai daya tarik para selebritis terkenal dunia datang ke rumahnya di Tjampuhan, Ubud, seperti : aktor Charlie Chaplin, sutradara Victor Baron von Plessen, novelis Beryl de Zoete, Barbara Hutton, Noel Coward, musikologis Colin McPhee, termasuk juga akademisi Belanda seperti Roelof Goris dan Willem Stutterheim (Atkins, 2012). Beberapa wisatawan yang datang memilih menetap dan menjadi ekspatriat, sekaligus menandakan ideologi kosmopolitanisme telah dimulai di Ubud.

Pada periode 1930-1940an, kesenian visual Bali yang masih murni mulai dipengaruhi oleh gaya kesenian baru yang dibawakan oleh ekspatriat Barat. Pada konteks ini, kebudayaan tinggi (high culture) yang di anut secara turun temurun oleh masyarakat lokal, secara perlahan digantikan oleh budaya populer (popular culture atau pop culture), sebagai manifestasi kebudayaan rendah (low culture) yang dibawa oleh ekspatriat ke Ubud. Karya seni lokal yang semula dibuat sebagai persembahan kepada Tuhan secara ikhlas, kemudian menjadi komoditas yang bernilai ekonomis tinggi. 
Pada tahun 1931, Walter Spies dan Puri Ubud bersama-sama mengorganisir pengiriman kelompok seniman dari Peliatan untuk mewakili pemerintah kolonial Belanda pada misi kesenian Paris Colonial Exhibition 1931 di Paris, Perancis (Saverse, 2001). Setelah kesuksesan misi kesenian tersebut, Walter Spies, Bonnet bersama dengan Raja Ubud - Tjokorda Gede Agung Sukawati, serta seniman lokal I Gusti Nyoman Lempad mendirikan asosiasi Pita Maha pada tahun 1936 dan berhasil beberapa kali mengadakan pameran seni di luar negeri. Pendirian asosiasi ini merupakan sebuah pemikiran yang revolusioner pada masanya sebagai hasil dari kolaborasi Barat dan Timur.

Semenjak kehadiran seniman ekspatriat, denyut pariwisata Ubud mulai berdetak, namun hal ini belum memberikan dampak signifikan bagi masyarakat lokal. Disini, tampak peran ekspatriat perintis lebih sebagai 'jembatan budaya' antara wisatawan asing dan orang lokal (Picard, 2006), melakukan 'transfer of knowledge' (baik kepada sesama ekspatriat maupun lokal) sekaligus mempengaruhi ideologi berkesenian seniman lokal (yang dikenal dengan gaya Kamasan) dengan genre seni Baratnya. Kesadaran masyarakat lokal terhadap potensi pariwisata masih rendah, dan menganggap menjual lukisan ke wisatawan sebagai pekerjaan sampingan saja.

Semakin lama posisi Ubud semakin tampak pada peta pariwisata dunia, seiring dengan semakin baiknya sarana dan prasarana transportasi, serta promosi tidak langsung dari para ekspatriat pada jaringan sosial mereka. Selanjutnya, pada periode tahun 1942 - 1966 merupakan masa transisi politik pemerintahan yang suram bagi ekspatriat, yakni proses dekolonialisasi Belanda dan pendudukan Jepang (1942 - 1945), meletusnya Gunung Agung (1963) serta gejolak elit politik Jakarta yang berujung pada pemberontakan berdarah dan genosida besar-besaran masyarakat Bali (1965-1966). Tahun 1966 ditandai dengan jatuhnya Soekarno dan rezim Orde Lama (1950 - 1966) digantikan oleh Orde Baru (1966 - 1998) dibawah kepemimpinan Presiden Soeharto. 
Dapat disimpulkan, pada tahap eksplorasi, mitos oriental 'Sorga Bali' (yang lahir dari perspektif kolonialis dan ide orientalisme Eropa), secara perlahan terus direkonstruksi, direproduksi dan menyesuaikan dengan imajinasi sorga versi Barat yang terkadang hiperbolis. Kedatangan ekspatriat di Ubud pada masa ini umumnya didominasi oleh rasa ingin tahu dan menjawab rasa penasaran, sekaligus mengkonfrontasi imaji sorga dan ide-ide orientalisme mereka sendiri mengenai Bali.

Pada tataran sosial dan ekonomi, hubungan antara ekspatriat dengan masyarakat lokal belum sepenuhnya cair, masih dibatasi oleh aturan-aturan kolonial, dan dibayangi oleh pengaruh Puri Ubud sebagai penguasa setempat. Ide revitalisasi kesenian Bali dapat juga dianggap sebagai kolonialisasi kesenian oleh ekspatriat Barat yang difasilitasi oleh Puri Ubud, yakni berupa dominasi asosiasi Pita Maha dalam dunia seni visual Ubud, serta aturan segregasi kelas yang diterapkan oleh Belanda. Pada tahap ini, proses transfer of knowledge telah terjadi antara ekspatriat dan masyarakat lokal, dan ideologi kapitalisme dan kosmopolitanisme Barat mulai diperkenalkan melalui seni dan pariwisata. Salah satunya adalah peran penting Bonnet dalam membuka 'pasar' dengan mengadaptasi kesenian dan kerajianan tangan lokal menjadi komoditas berupa souvenirs bagi wisatawan.

Tahapan ini memiliki perbedaan dengan model Butler yang asli, dimana yang mengambil inisiatif membangun pariwisata justru dari pihak luar, yakni pemerintah kolonial Belanda dan ekspatriat di Ubud, sementara inisiatif masyarakat lokal masih lemah dan belum terlibat secara mandiri. Dengan demikian, sejak tahapan eksplorasi, ekspatriat sebenarnya mulai mengkonversi modal budaya (penguasaan bahasa asing, intelektulitas dialogis, pengetahuan atas budaya setempat, kemampuan berkarya) dan modal sosial (jaringan pertemanan, hubungan dengan penguasa lokal dan keistimewaan rasial putih yang diperoleh dari segregasi kelas kolonial Belanda) menjadi modal ekonomi, yang bahkan bisa diwariskan sampai sekarang (contoh : Museum Puri Lukisan sebagai warisan intelektualitas ekspatriat dan galeri Antonio 
Blanco yang tetap eksis hingga saat ini). Selain itu, berbagai karya yang dihasilkan oleh para ekspatriat (lukisan, film, foto, rekaman audio dan buku oriental) memiliki nilai jual yang sangat tinggi di Eropa dan Amerika. Disini tampak bagaimana pertukaran sosial mulai terjadi, baik bagi ekspatriat maupun Puri Ubud, yang terbukti mampu memanfaatkan berbagai modal yang dimiliki ekspatriat untuk memperkuat eksistensi mereka pada ranah seni, budaya dan pariwisata, yang manfaatnya sosioekonomisnya masih bisa dinikmati sampai sekarang oleh masyarakat.

\section{Tahap Keterlibatan (The Involvement Stage)}

Tahap Keterlibatan (The Involvement Stage), terjadi pada periode 1960 - 1970an, ditandai dengan dimulainya kesadaran negara, masyarakat lokal dan ekspatriat untuk terlibat pada pengembangan pariwisata. Pada masa ini, kondisi fisik Ubud masih sangat alami dan belum menjadi destinasi utama pariwisata seperti sekarang, namun secara perlahan, keterlibatan negara, masyarakat lokal dan ekspatriat yang lebih mendalam dan serius pada pengembangan pariwisata.

Pada awal periode ini, Arie Smit datang dengan energi dan ide-ide kreatif baru, dengan mengajarkan seni lukis pada anak-anak muda di Penestanan. Beliau mengembangan aliran lukis baru yang disebut Young Artist. Memulai dengan enam orang, jumlah pengikut Arie Smit maningkat mencapai ratusan orang hanya dalam waktu beberapa tahun. Hasil lukisan anak- anak Penestanan ini laku keras di pasar Eropa dan mendominasi beberapa art shop Ubud (Dermawan T, 2010:79). Tampak bagaimana ekspatriat mulai secara terbuka memanfaatkan modal budaya (intelektualitas seni, kemampuan berkarya dan melihat kesempatan) dan modal sosial (jaringan seniman-seniman muda Ubud dan art dealers) yang mereka miliki menjadi modal ekonomi (melalu penjualan hasil karya anak-anak Penestanan) yang pada akhirnya berdampak positif pada ekonomi setempat, terutama pada masa-masa sulit meletusnya Gunung Agung tahun 1963. 
Pada periode ini, ekspatriat mulai berhubungan lebih dalam dan luwes pada orang lokal, beberapa berlanjut pada jenjang pernikahan. Han Snel, seniman ekspatriat Belanda yang datang pada 1940-an, telah menjadi pelukis kenamaan di Ubud, sekaligus bisa membangun usaha galeri, bungalow dan restoran di Jalan Kajeng, yang kini dikelola istrinya, Ibu Made Siti Snel. Selang dua tahun kemudian, seniman Antonio Blanco pun datang dan bertemu Tjokorda Gde Agung Sukawati. Beliau menikah dengan seorang gadis lokal pujaan hatinya, Ni Rondji dan memulai berkarya di Ubud (Han Snel dan Antonio Blanco, keduanya kemudian menganut agama Hindu dan menjadi warga negara Indonesia). Pada tahun 1974, Ubud menjadi parhatian dunia karena Ratu Elizabeth II dari kerajaan Inggris datang berkunjung (Mann, 2013), sekaligus mengangkat popularitas Ubud ke level baru.

Jika pada periode sebelumnya wisatawan asing yang datang ke Bali dominan dari Eropa dan Amerika, maka pada periode ini yang dominan adalah wisatawan dari Australia. Hal ini tidak lepas dari dibukanya jalur penerbangan langsung (direct flight) Australia ke Bali, tanpa harus singgah ke Jakarta terlebih dahulu. Pada tahun 1924, jumlah wisatawan asing ke Bali mencapai 213 orang, tahun 1926, terus naik menjadi 445 orang, pasca era The Great Depression (Depresi Besar) di awal tahun 1930-an, trend peningkatan ini berlanjut hingga pada tahun 1936 mencapai 2880 orang (Official Tourist Bureau, dalam Picard 1996; Ningtyas, 2916) dan kunjungan 24 ribu orang wisatawan pada tahun 1970 (BPS, 2019)

Keterlibatan negara pada pariwisata sejak rezim Orde Lama, dapat ditelusuri dari pembangunan Hotel Bali Beach oleh Presiden Soekarno pada tahun 1963 sebagai perhatian lebihnya pada pariwisata Bali sekaligus bagian pencitraan Indonesia sebagai bangsa yang baru di dunia internasional. Ketika itu, Presiden Soekarno dikenal dekat dengan jaringan seniman dan ekspatriat di Bali. Pada tahun 1968, gelombang wisatawan hippies mulai berdatangan di Bali, terutama di Kuta dan Ubud. 
Politik segregasi kelas yang diterapkan oleh pemerintah kolonial Belanda untuk membatasi interaksi antara wisatawan dan ekspatriat Barat terhadap masyarakat lokal, seolah diterapkan kembali oleh Orde Baru dengan membangun kawasan wisata terpadu mewah di Nusa Dua (sebagai imlementasi dari Rencana Induk Pengembangan Pariwisata di Bali yang disusun oleh konsultan Perancis, SCETO (Société Centrale pour l'Equipement Touristique Outre-Mer), bukti campur tangan pemerintah, sekaligus membatasi pergerakan wisatawan hippies di Bali pada tahun 1970-an karena dianggap dapat membawa pengaruh buruk pada moral anak-anak muda dan tatanan budaya masyarakat Bali.

Dampaknya, ribuan wisatawan asing backpackers kelas menengah yang diasosiasikan sebagai hippies akhirnya lebih memilih Kuta dan Ubud, dan tidak sedikit di antara mereka yang akhirnya menjadi ekspatriat di dua destinasi ini. Meskipun dianggap sebagai 'gangguan' dalam proses pembentukan dan wacana pembangunan pariwisata nasional yang dikonsepkan oleh Orde Baru, wisatawan hippies tetap menjadi kontributor bagi perkembangan pariwisata Bali pada era 1970-an (Ningtyas, 2016).

Keterlibatan ekspatriat tampak pada keberhasilan Puri Ubud untuk mengelola pariwisata berbasis puri sejak tahun 1930-an, yang kemudian berkembang menjadi model bagi pengembangan "pariwisata budaya" di Bali pada tahun 1970an (MacRae \& Putra, 2016: 202), yang bahkan menjadi doktrin pariwisata Bali sampai sekarang. Ide pengembangan 'Pariwisata Budaya' sebagai identitas pariwisata Bali diperkuat melalui Seminar Pariwisata Budaya Daerah Bali pada bulan Oktober 1971 yang diadakan oleh Gubernur Bali saat itu (Picard, 2006 : 186). Slogan 'Pariwisata Budaya' akhirnya diakui sebagai 'arah pariwisata yang benar dan pantas' untuk berlaku di Bali sampai sekarang. Disini tampak bagaiman upaya negara, dalam hal ini Pemerintah Pusat dan Pemerintah Daerah Bali untuk campur tangan dalam perkembangan pariwisata di Bali, salah satunya agar pariwisata yang berkembang selalu menjunjung tinggi 
budaya lokal dan terlindungi dari pengaruh-pengaruh asing, sebagaimana yang digariskan dalam Rencana Induk Pengembangan Pariwisata di Bali yang justru dikonsepkan oleh SCETO, konsultan asing dari Perancis.

Pada periode ini, pariwisata Ubud mulai booming dan para investor besar dari Jakarta turut terlibat pada proses tersebut. Semakin banyak wisatawan asing yang datang -termasuk para wisatawan asing kapal pesiar dari Padang Bai- menjadikan masyarakat lokal sadar akan potensi ekonomi yang muncul. Keterlibatan masyarakat lokal Ubud terhadap pariwisata mulai meningkat pada era 1970an. Pada tahun 1970, Ni Made Tjanderi, seorang mantan penjual kain di Sanur, mencoba membuka homestay pertama di Ubud, yang berlokasi di jalan Monkey Forest. Ketika itu, wisatawan yang menginap didominasi kaum Hippies sebagai alternatif penginapan yang lebih murah dibandingkan hotel. Tjanderi Homestay menjadi pionir bagi usaha akomodasi berikutnya di Ubud, seperti Mutiara, Menaradan Okawati's Cottage (Mann, 2013).

Selanjutnya ada Ni Wayan Murni, gadis lokal Penestanan yang menjadi pionir pariwisata Ubud dengan membuka sebuah restoran di tengah-tengah desa menggunakan namanya sendiri, yakni Warung Murni (Murni's Warung). Beberapa pertimbangannya : ibunda beliau sebelumnya seringkali memasak untuk Walter Spies, dan banyak tamu-tamu Tjampuhan Inn (bekas kediaman Walter Spies yang dijadikan bungalow) menanyakan tempat membeli makanan, selain itu orang tua Murni memiliki sepetak tanah di ujung jembatan kayu yang sangat strategis.

Pada awalnya Murni belajar mengenai makanan Barat dari para tamu, berupa makanan- makanan yang sangat asing bagi orang lokal. Selanjutnya, bersama suami keduanya, seorang Amerika bernama Pat, Murni belajar mennyajikan sandwich, sup dan bir dingin (Mann, 2013 : 115). Tak lama, Warung Murni menarik perhatian wisatawan asing dan ekspatriat, yang menjadi kemudian langganannya, termasuk 
Arie Smit dan Antonio Blanco, serta menjadi restoran favorit tokoh dunia seperti Richard Branson, David Copperfield dan Richard Gere.

Pada masanya, warung Murni dianggap sebagai satu-satunya 'restoran' yang layak di Ubud. Saat ini, Ibu Murni telah menjadi legenda hidup Ubud dengan banyak teman ekspatriat. Selain di bidang makanan, Ibu Murni juga membuka rumahnya sebagai hotel kecil. Usaha Warung Murni terus berkembang dengan lebih dari 60 orang pegawai, dan merambah usaha villa dan spa. Bersama dengan Jonathan Copeland, seorang ekspatriat Irlandia, Ibu Murni menjadi co-author buku-buku internasional.

Pada tahun 1970-an adalah masa mulai booming pariwisata massal, ketika itu Ubud hanya memiliki empat hotel, sebuah penginapan, serta belasan galeri (Picard, 2006 :123). Meskipun baru sedikit, namun pada masa ini jiwa wirausaha lokal mulai bermunculan, baik sebagai broker seni pertunjukan tradisional, menyelenggarakan pementasan, dan membuka berbagai usaha dagang kecil-kecilan, seperti warung minuman, kerajinan tangan (handicraft) dan lukisan. Selain keterlibatan oleh masyarakat lokal, tidak dapat dipungkiri bahwa kesempatan emas pada periode ini juga digunakan oleh para ekspatriat untuk memperoleh keuntungan ekonomis dari pariwisata yang mulai bergeliat kencang di Ubud. Relasi ekonomi pun tercipta dan meluas melalui simbiosis antara masyarakat lokal dengan ekspatriat yang datang, baik sebagai mantan hippies, investor, broker maupun pengusaha pariwisata.

\section{Tahap Pengembangan (The Development Stage)}

Tahap Pengembangan terjadi pada periode 1980 - 2000an, Sejak pengembangan bandara di Tuban pada tahun 1966 dan booming pariwisata massal pada era 1970-an, pariwisata Ubud telah berhasil menarik minat ratusan ribu wisatawan asing setiap tahunnya. Bertahun-tahun kemudian, orang lokal dan ekspatriat (beberapa termasuk veteran hippies), yang merintis usaha sejak tahun 70- 
an menjadi semakin eksis seiring dengan laju pariwisata Ubud. Pada periode ini, taraf ekonomi masyarakat Ubud meningkat, jauh berbeda dengan desa-desa lain di sekitarnya yang belum tersentuh pariwisata.

Pada tahun 1978, Agung Rai yang sebelumnya menjual lukisan kepada tamu asing di Kuta dan Sanur mulai membuka galeri lukisan di Peliatan, dan berhasil merintis museum ARMA (Agung Rai Museum of Art) pada tahun 1996. Tahun 1982, Suteja Neka yang berteman sangat baik dengan Arie Smit dan Rudolf Bonnet membuka museum seni di Campuhan. I Nyoman Rudana, mantan penjual lukisan di Sanur, membuka museum tahun 1995. Semuanya adalah para wirausahawan lokal yang seringkali berhubungan dengan tamu asing dan ekspatriat, mereka berjuang dari nol dan bisa melihat kesempatan emas dari berkembangnya pariwisata di Ubud. Selain di bidang ekonomi, beberapa ekspatriat generasi ini mulai eksis di bidang literasi seni dan budaya, salah satunya adalah Bruce W. Carpenter yang menetap di Ubud pada tahun 1985, beliau telah menulis lebih dari 20 buku mengenai seni dan budaya Indonesia. Tampak kepemilikan usaha lokal meningkat seiring tumbuhnya kesadaran masyarakat lokal terhadap potensi pariwisata. Para pengusaha lokal ini sekaligus menjadi tulang punggung keberlangsungan pariwisata Ubud sampai sekarang.

Pada tahap ini, hubungan sosial antara masyarakat lokal dan ekspatriat semakin berkembang pada tahapan personal. Hubungan ini dimanifestasikan dalam berbagai bentuk, seperti : pola keluarga asuh, pembiayaan pendidikan anak angkat bahkan ke perkawinan antar bangsa. Tidak sedikit orang lokal yang dipercaya mengelola berbagai usaha orang asing di luar negeri, maupun sebagai perpanjangan tangan ekspatriat di Ubud karena hubungan baik mereka. Sebagai contoh Arie Smit, sudah lama tinggal bersama dan dianggap sebagai bagian dari keluarga Suteja Neka, bahkan namanya tercatat dalam Kartu Keluarga Suteja Neka. 
Anak-anak mantan generasi Young Artist banyak yang menjadi seniman dan mandiri secara ekonomi, mereka mendirikan galeri-galeri kecil, bahkan ada yang berhasil pameran hingga ke luar negeri. Disini tampak peran ekspatriat Arie Smit membantu kemajuan seni rupa dan ekonomi masyarakat lokal, yakni dengan memberikan mereka bekal pengetahuan (transfer of knowledge) serta kemampuan mengaplikasikannya menjadi modal ekonomi, yang berguna bagi kehidupan dan masa depan anak-anak tersebut.

Pada tahun 80 - 90an, sarana prasarana transportasi di Ubud mulai ditingkatkan oleh pemerintah, beberapa jalan utama mulai di aspal meskipun masih kasar dan belum dilengkapi lampu penerangan. Selain itu, di bawah open door policy kepemimpinan Presiden Soeharto, sejak tahun 1983 para wisatawan asing dari 48 negara tertentu dapat menikmati fasilitas bebas visa masuk Indonesia (Keppres RI No 15 tahun 1983). Tampak bahwa pemerintah daerah dan pemerintah pusat turut memiliki andil bagi kemajuan pengembangan pariwisata pada masa ini.

Meskipun secara umum kondisi Ubud masih sederhana, wisatawan asing tetap mengalir deras terutama untuk menonton pertunjukan tari tradisonal, melihat lukisan dan bercengkrama di warung-warung lokal. Pertunjukan tari tradisional Bali marak digelar di halaman Puri Ubud. Setiap kali pementasan, rata-rata melibatkan antara 50 sampai 60 orang lokal, yang tentunya memberikan dampak ekonomi positif bagi masyarakat. Mereka sangat antusias menerima pariwisata yang datang ke daerahnya. Dampaknya, komodifikasi berupa produk seni massal membanjiri pasar-pasar seni, yang tentunya berharga lebih murah dan berkualitas rendah.

Sementara di sisi lain, investor-investor besar mulai mengincar tanah-tanah hijau di pelosok Ubud, terutama yang memiliki pemandangan indah, seperti di tepi jurang maupun sempadan sungai. Umumnya para investor datang karena mengalihkan investasinya dari sesak dan mahalnya biaya pembangunan di Nusa 
Dua, Kuta dan wilayah Bali Selatan lainnya. Pada tahun 1980-1990an, harga tanah di di Ubud, terutama di lereng jurang maupun tepi sungai yang jauh dari jalan besar memang sangat murah karena dianggap tenget (angker), dihuni mahluk halus yang seram, tidak produktif untuk perkebunan dan tidak menguntungkan bagi masyarakat lokal.

Salah satu ekspatriat yang sukses membangun bisnis dari derasnya aliran Sungai Ayung adalah Nigel Mason dan istrinya, Made Karyani atau populer dengan nama Yanie Mason, seorang gadis Bali. Mereka sejak 1989 mendirikan BAR (Bali Adventure Rafting), sebagai operator white water rafting pertama di Ubud sekaligus pionir wisata petualangan di Ubud. Pada tahun 1992, mereka mengembangkan BAT (Bali Adventure Tours) (sekarang BAR dan BAT sudah berganti menjadi Mason Adventures, dengan lingkup produk dan jasa yang lebih luas). Tidak puas sampai disana, tahun 1997, mereka mengembangkan Elephant Safari Park di Desa Taro yang kemudian menjadi Elephant Safari Park Lodge and Spa (Mann, 2013). Ini merupakan contoh sukses kolaborasi antara Barat dan Timur di bidang ekonomi pariwisata.

Periode tahun 1990-an tidak terlepas dari beberapa krisis besar yang menghantam dunia pariwisata global serta mengakibatkan perkembangan pariwisata di Ubud melambat, di antaranya Perang Teluk (Gulf War) di Timur Tengah tahun 1991, isu wabah kolera di Bali antara tahun 1994 - 1996, dan krisis moneter Asia tahun 1997 - 1998, referendum Timor Timur, sekaligus jatuhnya era Orde Baru yang digantikan oleh era Reformasi. Meskipun di hantam berbagai krisis, perlahan pembangunan hotel lokal hingga jaringan internasional terus berlanjut di Ubud, termasuk pemasaran Ubud secara masif di berbagai platform media oleh hotel-hotel jaringan internasional. Peran negara tampak ketika Gubernur Bali saat itu justru menjadi perantara kooperatif sekaligus agen para investor, baik lokal maupun asing (Nordholt, 2007 dalam Sanjaya, 2018). 
Pada fase prainvestasi, sosialisasi berupa peparuman dilakukan oleh agen investasi bersama dengan desa adat dan masyarakat lokal. Agen investasi bisa saja ekspatriat yang dianggap paham mengenai Bali dan punya keahlian negosisasi, maupun orang lokal Bali yang dipercaya. Pelibatan masyarakat bertujuan membuka celah-celah komunikasi agar proses investasi bisa terwujud lebih cepat. Fase pembangunan, masyarakat dilibatkan dalam proses perijinan dengan diiming-imingi janji berupa CSR, donasi upacara, kuota pekerja lokal dll. Pada fase pengelolaan, perusahaan umumnya menepati janji-janjinya, menggunakan kearifan lokal Tri Hita Karana, budaya dan sustainability sebagai jargon pariwisata, serta berkolaborasi dengan desa adat untuk mendapatkan 'benteng perlindungan' dari masyarakat setempat (Sanjaya, 2018). Meskipun kepemilikan lahan oleh pihak asing dilarang dalam peraturan perundang-undangan di Indonesia, namun banyak di antaranya yang melakukan praktik pinjam nama lokal atau praktik nominee, yang tentunya difasilitasi oleh agen lokal. Salah satu dampaknya, perubahan fisik Ubud masif terjadi karena alih fungsi lahan pertanian menjadi sarana akomodasi pariwisata, lemahnya perencanaan tata kawasan serta kurangnya kontrol dari otoritas pemerintahan setempat.

Pada periode ini ekspatriat di Ubud memiliki peran penting. Salah satunya adalah menjadi agen, sebagai jembatan ide sekaligus jembatan modal antara investor luar negeri dan eksekutor di dalam negeri. Beberapa peran yang umum dilakukan oleh ekspatriat di sektor ini, seperti menjadi konsultan, tim ahli, arsitek dan manajemen level atas. Ini berarti mereka memiliki menggunakan berbagai modal (budaya, sosial, ekonomi, dan simbolik) sebagai representasi pemilik modal utama yang memiliki power dan kemampuan tawar pada kegiatan investasi yang dilakukan, termasuk pada fase-fase di atas. 


\section{Tahap Konsolidasi (The Consolidation Stage)}

Tahap konsolidasi di Ubud terjadi pada periode tahun 2001 - sekarang, seiring hype pergantian abad yang populer disebut Millenium, musibah bom Bali dan upaya pemulihannya, serta revolusi besar-besaran di bidang teknologi, informasi dan platform media sosial. Di awal tahun 2001, pasca kemeriahan Millenium di berbagai penjuru dunia, tampaknya denyut perekonomian di seluruh kawasan Ubud terhubung erat dengan pariwisata dan komunitas ekspatriat yang ada di dalamnya.

Bali dan Ubud, secara umum dilihat sebagai tempat yang nyaman dan aman, sehingga investor tidak segan menanam modal mereka di tempat ini. Dampaknya, pembangunan berbagai sarana akomodasi pariwisata, seperti bungalow, homestay, villa dan hotel, baik skala kecil maupun besar, yang dimiliki oleh orang lokal, jaringan nasional dan internasional, sudah tidak bisa dibendung. Beragam bentuk usaha, seperti SPA, restoran, rafting, kafe hingga kursus bahasa asing, dan kursus bahasa Indonesia bagi ekspatriat turut bermunculan. Pada tahap ini, pembangunan berlebihan sudah mulai terjadi dan merambah pada desa-desa lain di sekitarnya. Potensi ekonomi yang muncul dari pariwisata dan ramainya komunitas ekspatriat berdampak pada semakin tingginya permintaan pasar terhadap beragam jenis properti di Ubud. Kesempatan ini dilihat oleh mata jeli seorang ekspatriat Jerman, Ramon Genz dan istrinya, Ni Luh Putu Citrawati untuk membuka sebuah kantor agen properti, dengan nama Ubud Property sejak tahun 2001 yang kini menjadi sangat populer dan menjadi acuan ekspatriat untuk membeli atau menyewa properti di Ubud.

Pada tahun 2002 dan 2005, dua musibah besar tiba-tiba menghentak Bali dan membuka mata dunia. Pertama, pada 12 Oktober 2002, terjadi serangkaian peristiwa pengeboman bunuh diri di tiga lokasi berbeda, yakni di Paddy's Pub, Sari Club (keduanya di Legian, Kuta) dan di dekat Kantor Konsulat Amerika di Renon, Denpasar. Kedua, di Kuta dan Jimbaran pada waktu yang hampir bersamaan. 
Musibah ini menelan ratusan korban jiwa maupun luka-luka. Para korban umumnya adalah wisatawan asing dan domestik, ekspatriat serta para pekerja lokal.

Pemerintah dan pelaku pariwisata mencoba untuk menghidupkan kembali industri pariwisata Bali dengan berbagai kampanye dan event berskala internasional. Di antaranya penyelenggaraan PATA Conference di Nusa Dua, pertemuan ASEAN Summit yang dihadiri para pemimpin se-Asia Tenggara dan perdana Menteri Australia, serta kunjungan Presiden Amerika, George, W Bush pada tahun 2003. Selain itu, bantuan pemulihan Bali juga diberikan oleh pemerintah Australia melalui konsulatnya dengan membiayai pembangunan beberapa instalasi rumah sakit di Bali (indonesia.embassy.gov.au, 2006) Selain pemerintah, ekspatriat juga berusaha membantu para korban dengan berbagai cara.

Pada film dokumenternya, Jero Asri Kerthyasa, (ekspatriat Australia dengan nama asli Jane Gillespie, istri dari Tjokorda Raka Kerthayasa atau Cok Ibah dari Puri Ubud), mengatakan bahwa pasca tragedi pemboman, ia dan teman-temannya mencoba membantu di rumah sakit, menggalang dana dan melakukan berbagai hal untuk membantu para korban. Tragedi pengeboman tahun 2002 menghancurkan keseluruhan reputasi Bali sebagai tempat yang damai, aman dan nyaman, sekaligus memberikan dampak yang luar biasa bagi industri pariwisata Bali dan Indonesia. Pasca peristiwa tersebut, eksodus besar besaran terjadi. Berbagai perusahaan milik asing di Bali memulangkan staf ekspatriat mereka, yang sebagian besar berasal Australia (Henderson, 2002). Tidak hanya di Indonesia, peristiwa ini juga berdampak pada beberapa negara Asia lainnya, seperti Malaysia, Thailand, Vietnam. Selain travel warning, dampak lanjutannya adalah krisis sosial dan ekonomi bagi masyarakat Bali yang kehilangan mata pencaharian mereka. Pasca tragedi, pendapatan rata-rata pedagang di Pasar Ubud anjlok sebesar 71\% dan di Pasar Sukawati turun sebesar 80\% (World Bank, 2003). 
Periode ini merupakan masa suram bagi dunia pariwisata Ubud, hotel, jalanan dan toko- toko sepi tanpa pengunjung. Menyikapi masa sulit ini, beberapa ekspatriat mencoba berinovasi untuk menarik kembali wisatawan dan membawa perubahan Ubud ke arah yang lebih baik. Salah satunya adalah Janet de Neefe, istri dari Ketut Suardana, pemilik Casa Luna Restaurant yang berhasil menyelenggarakan Ubud Writers and Readers Festival (UWRF) pertama pada tahun 2004. Sejak kesuksesan penyelenggaraan pertama, event ini menjadi platform tahunan bergengsi bagi penulis nasional dan luar negeri untuk go international. Melanjutkan kesuksesan UWRF, Janet kembali berinovasi dengan menyelenggarakan Ubud Food Festival tahun 2015, den saat ini berkembang menjadi festifal kuliner bergengsi dan menjadi incaran sponsorsponsor besar. Jika sebelumnya Ubud lebih dikenal karena wisata seni dan budayanya, sekarang Ubud juga dikenal sebagai salah satu pusat literasi internasional sekaligus pusat wisata kuliner Bali.

Ekspatriat berikutnya adalah Meghan Pappenheim, seorang instruktur yoga asal Amerika yang tiba di Bali tahun 1992. Pada tahun 2002, ia bersama suaminya Kadek Gunarta, pengelola galeri dan seniman asli Ubud mencoba membantu industri pariwisata Ubud dengan membuat website bernama balispirit.com. Website ini menghubungkan antara pasar wisatawan asing dengan beberapa industri lokal dan yoga studio di Ubud secara online. Ketika itu, pengembangan yoga di Ubud sangat terbatas dan ekslusif, hanya ada beberapa instruktur yang mengajar secara rutin. Menyadari potensi ekonomi pengembangan yoga dan holistic life style di Ubud mereka membangun sebuah yoga studio di jalan Hanoman, Ubud. Bangunan studio ini terdiri dari dua laintai, lantai dua digunakan untuk workshop dan latihan yoga, sedangkan lantai dasar digunakan sebagai kafe kecil yang menyediakan minuman sehat organik. Pada 2007, mereka membangun Yoga Barn, dan pada tahun 2008 bersama beberapa teman ekspatriatnya, pasangan ini menjadi mengorganisir event bertajuk Bali Spirit Festival, yang sukses meraih berbagai penghargaan dan menjadi event tahunan kelas 
dunia. Berkat kerja keras pasangan ini, Ubud dikenal dunia sebagai destinasi yoga dan holistic life style.

Menandai era baru bagi pariwisata Ubud adalah pembukaan Starbuck Café pada tahun 2010, berlokasi di tengah-tengah Ubud sentral Ubud, tidak jauh dari Puri Ubud. Keberadaan Starbuck marak dibahas pada berbagai forum dan media sosial oleh para ekspatriat, ada yang pro dan banyak pula yang tidak setuju. Umumnya ekspatriat yang kontra beranggapan bahwa Starbuck Ubud adalah simbol globalisme, kapitalisme dan modernisme yang tidak sesuai dengan nilai-nilai lokal. Selain itu, film Eat, Pray Love yang dibintangi Julia Roberts tahun 2010, meningkatkan popularitas Ubud, kemudian generasi ekspatriat baru mulai muncul di Ubud, yakni para Digital Nomads dan New Agers yang semakin eksis dengan gaya hidup nomadik dan spiritualitas ala barat yang mereka bawa.

Tahapan konsolidasi ditandai dengan semakin banyaknya wisatawan yang datang, dan perekonomian lokal menjadi sangat tergantung pada pariwisata. Pada tahun 2012, diperkirakan 80 persen pariwisata Bali dikuasi penanam modal asing (Kompas, 2012; Republika, 2012). Di tahap ini, pariwisata Ubud dipasarkan secara masif, terutama oleh investor dan para pelaku bisnis. Tampak kehadiran berbagai international chain hotel dan perusahaan franchise besar, seperti gerai Starbuck dan Polo Ralph Lauren di Ubud sentral. Kemacetan panjang seringkali tidak terhindarkan, terutama pada musim liburan dan hal ini dikeluhkan oleh masyarakat lokal dan ekspatriat yang menetap dan bekerja di Ubud. Upaya konsolidasi antara pemerintah, pelaku pariwisata, masyarakat dan ekspatriat tampak ketika kondisi industri pariwisata Ubud mengalami pasang surut, terutama yang disebabkan oleh tragedi pengeboman tahun 2002 dan 2004. 


\section{Tahap Stagnasi (The Stagnation Stage)}

Berdasarkan pada hasil penelitian, saat ini ekspatriat di Ubud belum masuk pada tahap staganasi walaupun industri pariwisata Ubud pernah mengalami masa pasang surut (Note : penelitian ini dilakukan sebelum pandemi Covid-19 .red). Adapun beberapa indikator yang bisa menjadi acuan Ubud belum masuk pada tahap ini antara lain :

1. Jumlah kehadiran ekspatriat di Ubud belum mencapai puncaknya, terutama karena adanya trend baru gaya hidup holistik, kehadiran pensiunan dan kesempatan usaha yang terbuka, terutama ekspatriat muda pada ranah digital.

2. Meskipun Ubud telah menjadi destinasi yang padat, namun belum mencapai atau melebihi carrying capacity-nya. Kebanyakan ekspatriat cenderung memilih di wilayah pinggiran Ubud karena lebih tenang dan harga properti yang lebih murah.

3. Meskipun kehadiran pariwisata dan ekspatriat berpotensi menimbulkan masalah baru pada aspek sosial, ekonomi dan lingkungan, namun sejauh ini permasalahan tersebut dalam batas yang wajar.

4. Kehadiran berbagai sarana pariwisata tidak menjadi terpisah dengan Ubud secara geografis (di bandingkan dengan Kawasan Pariwisata Terpadu Nusa Dua).

5. Kehadiran jenis atraksi pariwisata baru yang dibawa oleh ekspatriat hanya menjadi atribut baru, dan tidak menggantikan atraksi yang lama yang sudah menjadi identitas Ubud.

6. Ubud masih menjadi salah satu daya tarik pariwisata Bali dan masih berpotensi untuk terus dikembangkan ke arah yang positif.

7. Saat ini, dengan berbagai kuunggulan kompetitifnya Ubud masih bisa bersaing dengan berbagai destinasi wisata lain di Bali maupun di Indonesia. 
Dengan demikian, perkembangan ekspatriat di Ubud saat ini adalah pada tahapan konsolidasi. Mereka membawa pengaruh yang besar pada industri pariwisata dan citra Ubud pada skala internasional. Untuk memperoleh gambaran lebih ringkas mengenai perkembangan ekspatriat di Ubud, dapat dilihat pada tabel di bawah ini :

Tabel 1. Perkembangan Ekspatriat di Ubud Mengadaptasi Model T.A.L.C

\begin{tabular}{|c|c|c|c|}
\hline No & TAHAPAN & $\begin{array}{c}\text { PERIODE } \\
\text { WAKTU }\end{array}$ & INDIKATOR-INDIKATOR \\
\hline 1 & Eksplorasi & 1920 -1950an & $\begin{array}{l}\text { - Jumlah ekspatriat di Ubud masih sangat terbatas } \\
\text { - Politik segregasi kelas masih diterapkan oleh Belanda }\end{array}$ \\
\hline & & & $\begin{array}{l}\text { - Ekspatriat mengharumkan nama Bali, sekaligus } \\
\text { merekontruksi dan mereproduksi mitos sorga Bali di } \\
\text { dunia internasional melalui berbagai karya visual dan } \\
\text { tulisan } \\
\text { - Kedatangan ekspatriat didominasi rasa penasaran dan } \\
\text { ingin tahu, serta mengkonfrontasi imaji sorga yang mereka } \\
\text { bawa. } \\
\text { - Ubud menjadi destinasi alternatif ekspatriat yang ingin } \\
\text { menjauh dari Kuta } \\
\text { - Atraksi utama Ubud adalah menikmati keindahan alam, } \\
\text { seni, budaya, bertemu masyarakat dan bertemu Walter } \\
\text { Spies, ekspatriat Ubud asal Jerman yang sangat popular } \\
\text { - Dimulainya ideologi kosmopolitasnisme di Ubud dari } \\
\text { ekspatriat dan wisatawan internasional } \\
\text { - Adanya transfer of knowledge dari pihak ekspatriat dan } \\
\text { masyarakat lokal } \\
\text { - Kesenian Bali yang masih murni mulai dipengaruhi oleh } \\
\text { gaya berkesenian Barat yang dibawa ekspatriat, ideologi } \\
\text { Barat (kapitalisme) mempengaruhi ideologi lokal } \\
\text { (kolonalisasi pemikiran) } \\
\text { - Dimulainya komodifikasi pada karya seni, terutama seni } \\
\text { visual } \\
\text { - Kesadaran masyarakat lokal terhadap potensi pariwisata } \\
\text { masih lemah, dan tidak tergantung sepenuhnya pada } \\
\text { pariwisata } \\
\text { ekspatriat dengan masyarakat lokal belum sepenuhnya } \\
\text { cair, masih dibatasi oleh aturan- aturan kolonial, dan } \\
\text { dibayangi oleh pengaruh Puri Ubud sebagai penguasa } \\
\text { setempat. }\end{array}$ \\
\hline
\end{tabular}




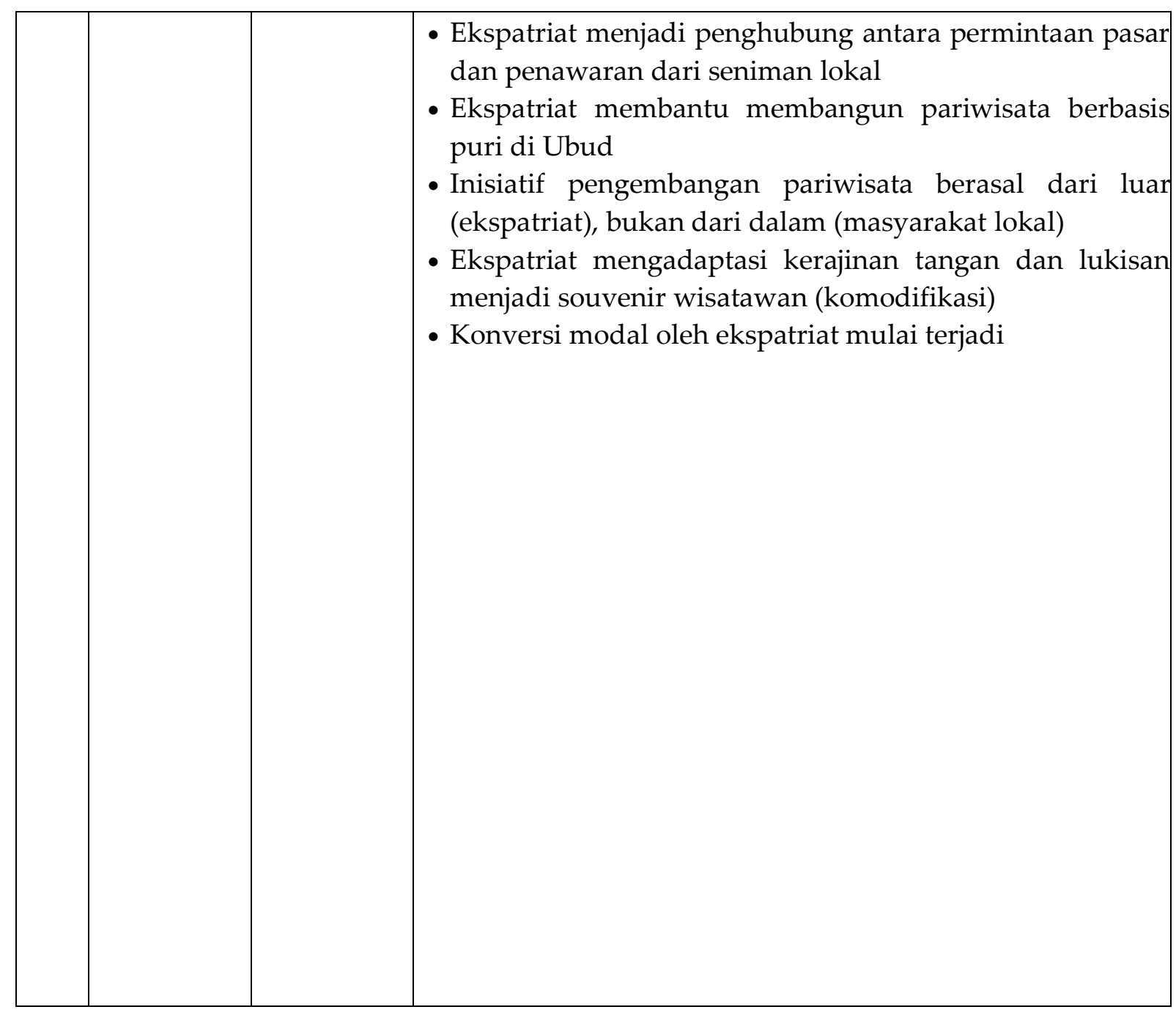




\begin{tabular}{|c|c|c|c|}
\hline 2 & Keterlibatan & $\begin{array}{c}\text { 1960-an } \\
\text { hingga 1970- } \\
\text { an }\end{array}$ & $\begin{array}{l}\text { - Jumlah wisatawan dan ekspatriat mulai meningkat } \\
\text { - Dimulainya kesadaran negara, masyarakat lokal dan } \\
\text { ekspatriat untuk terlibat lebih serius pada pengembangan } \\
\text { pariwisata Ubud. } \\
\text { - Kondisi fisik Ubud masih sangat alami dan belum menjadi } \\
\text { destinasi utama pariwisata } \\
\text { - Arie Smit datang dengan energi dan ide-ide kreatif baru, } \\
\text { membawa gaya lukisan Young Artist } \\
\text { - Ekspatriat mulai secara terbuka memanfaatkan modal } \\
\text { budaya (intelektualitas seni, kemampuan berkarya dan } \\
\text { melihat kesempatan) dan modal sosial (jaringan seniman- } \\
\text { seniman muda Ubud dan art dealers) yang mereka miliki } \\
\text { menjadi modal ekonomi, yang kemudian didistribusikan } \\
\text { kepada masyakarat lokal } \\
\text { - Beberapa ekspatriat mulai menjalin hubungan lebih } \\
\text { dengan orang lokal dan berlanjut pada jenjang pernikahan } \\
\text { (Han Snel dan Ibu Siti, Antonio Blanco dan Ni Rondji, Jane } \\
\text { Gillespie dan Cok Ibah dari Puri Ubud)) } \\
\text { - Kedatangan wisatawan Australia lebih dominan karena } \\
\text { kebijakan penerbangan } \\
\text { - Keterlibatan pemerintah melalui pembukaan Bali Beach } \\
\text { Hotel tahun } 1963 \text { dan pengembangan Kawasan resor } \\
\text { mewah Nusa Dua, menyebabkan kehadiran gelombang } \\
\text { kaum hippies di Ubud } \\
\text { - Adaptasi model pariwisata berbasis puri di Ubud menjadi } \\
\text { - Basar pengembangan jenis pariwisata budaya untuk Bali } \\
\text { - Investor Jakarta mulai mengambil peran } \\
\text { yang muncul, dan mulai terlibat langsung sebagai } \\
\text { wirsausaha pariwisata mandiri skala kecil, menyediakan } \\
\text { produk maupun jasa (Tjanderi, Murni) }\end{array}$ \\
\hline & & & $\begin{array}{l}\text { - Simbiosis ekonomi mulai tercipta dan meluas antara } \\
\text { ekspatriat dan masyarakat lokal }\end{array}$ \\
\hline
\end{tabular}




\begin{tabular}{|c|c|c|c|}
\hline 3 & $\begin{array}{l}\text { Pengemban } \\
g \text { an }\end{array}$ & $\begin{array}{l}\text { 1980-an } \\
\text { sampai 2000- } \\
\text { an }\end{array}$ & 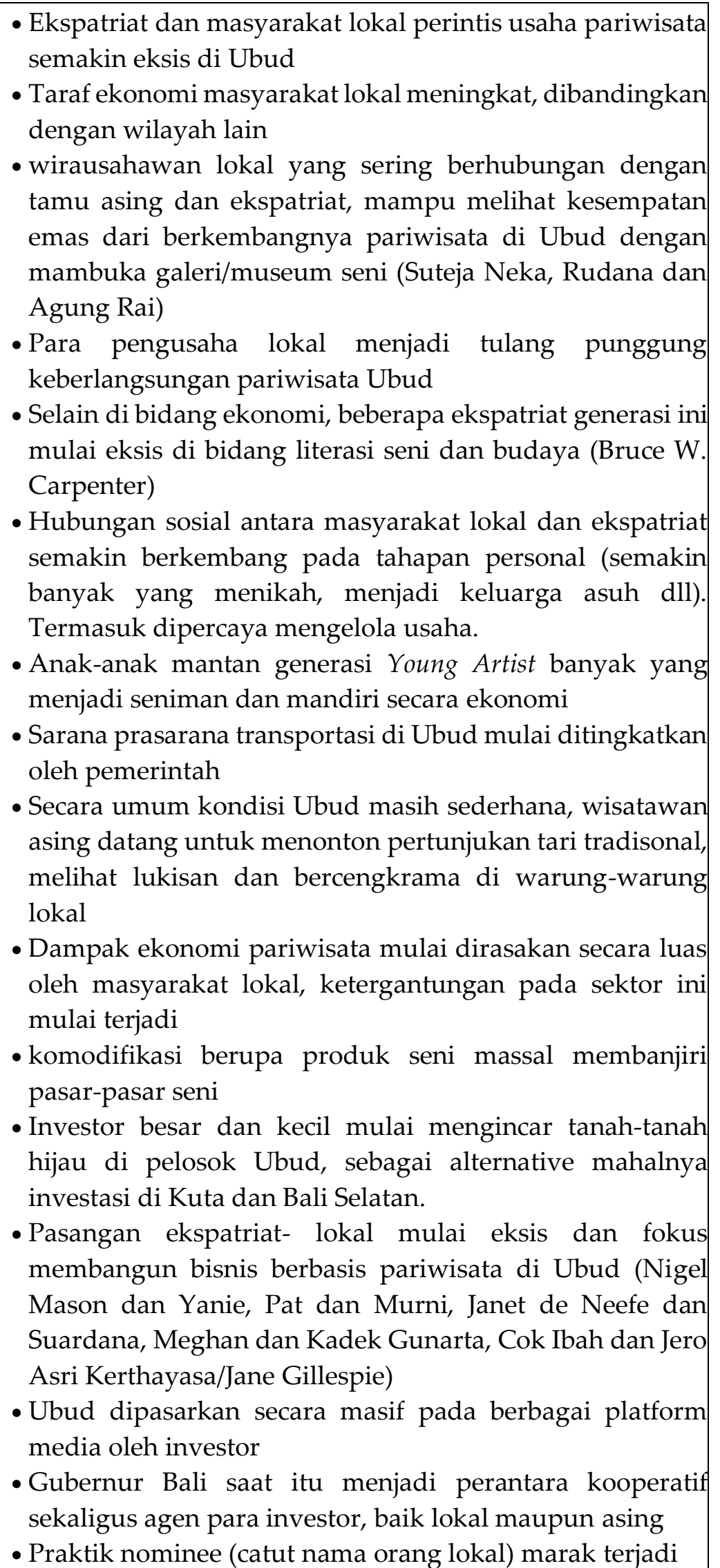 \\
\hline
\end{tabular}




\begin{tabular}{|c|c|c|c|}
\hline & & & $\begin{array}{l}\text { - Pada masa ini, banyak eksptriat berperan penting yang } \\
\text { menjadi agen investasi, yakni sebagai jembatan ide } \\
\text { sekaligus jembatan modal antara investor luar negeri dan } \\
\text { eksekutor di dalam negeri. } \\
\text { - Ekspatriat menjadi representasi pemilik modal utama } \\
\text { yang memiliki } \\
\text { power dan kemampuan tawar pada kegiatan investasi yang } \\
\text { dilakukan } \\
\text { - Perubahan fisik Ubud berubah secara masif karena alih } \\
\text { fungsi lahan pertanian menjadi sarana akomodasi } \\
\text { pariwisata, lemahnya perencanaan tata kawasan serta } \\
\text { kurangnya kontrol dari otoritas pemerintahan setempat. }\end{array}$ \\
\hline 4 & Konsolidasi & $\begin{array}{l}2001 \text { hingga } \\
\text { sekarang }\end{array}$ & $\begin{array}{l}\text { - International hype berupa momen pergantian abad yang } \\
\text { populer disebut Millenium } \\
\text { - Revolusi besar-besaran di bidang teknologi, informasi dan } \\
\text { platform media sosial. } \\
\text { - Perekonomian di seluruh kawasan Ubud terhubung erat } \\
\text { dengan pariwisata dan komunitas ekspatriat yang ada di } \\
\text { dalamnya. } \\
\text { - Semakin tingginya permintaan pasar terhadap beragam } \\
\text { jenis properti di Ubud, eksptriat melihat ini sebagai } \\
\text { kesempatan (Ramon Ganz dan Ni Luh Putu Citrawati - } \\
\text { Ubud Property) }\end{array}$ \\
\hline
\end{tabular}




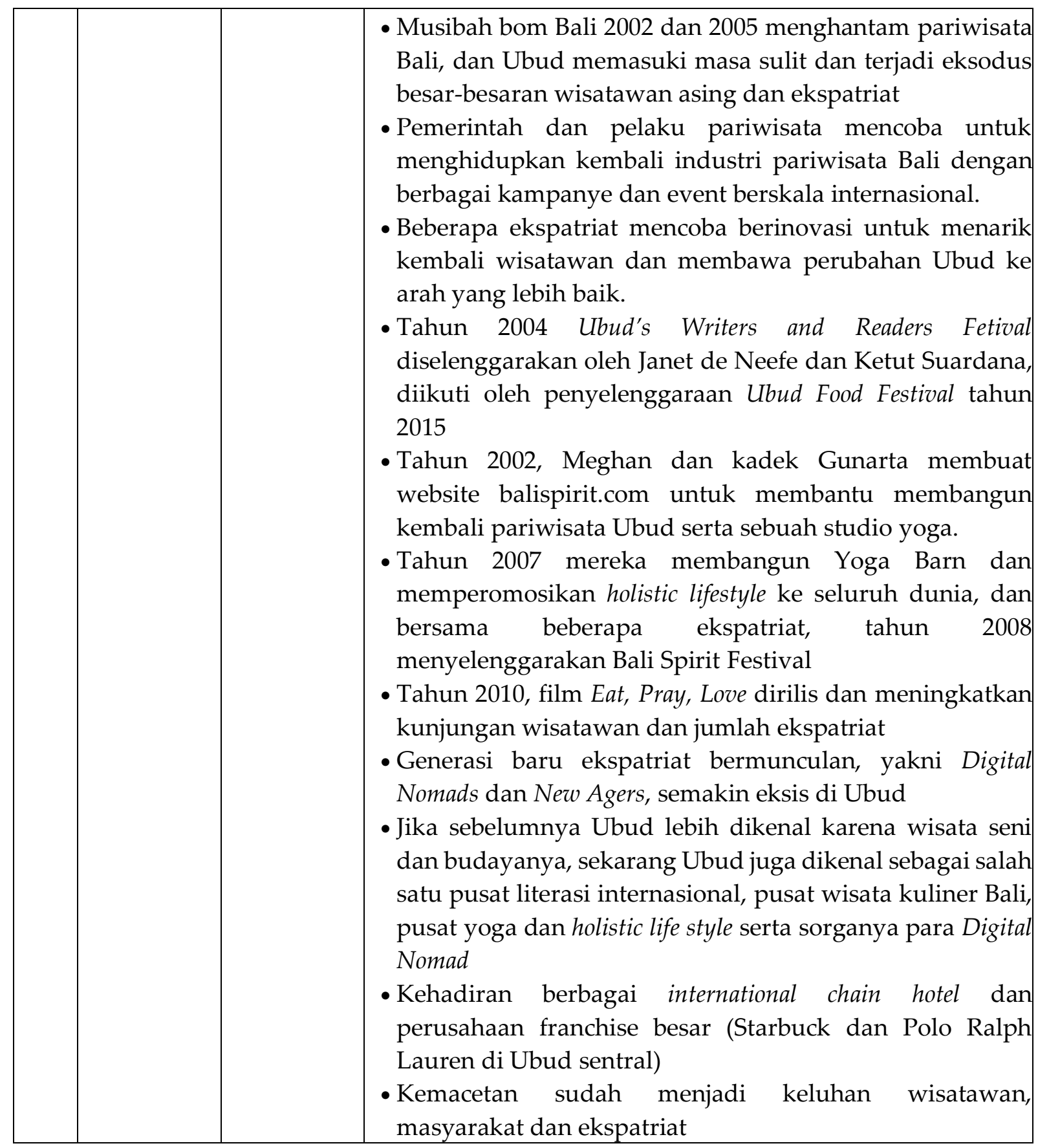




\begin{tabular}{|c|c|c|c|}
\hline 5 & Stagnasi & $\begin{array}{l}\text { Belum } \\
\text { Terjadi }\end{array}$ & $\begin{array}{l}\text { - Jumlah kehadiran ekspatriat di Ubud belum mencapai } \\
\text { puncaknya } \\
\text { - Meskipun Ubud telah menjadi destinasi yang padat, } \\
\text { namun belum mencapai atau melebihi carrying capacity- } \\
\text { nya. } \\
\text { - Meskipun kehadiran pariwisata dan ekspatriat berpotensi } \\
\text { menimbulkan masalah baru pada aspek sosial, ekonomi } \\
\text { dan lingkungan, namun sejauh ini permasalahan tersebut } \\
\text { dalam batas yang wajar. } \\
\text { - kehadiran berbagai sarana pariwisata tidak menjadi } \\
\text { terpisah dengan Ubud secara geografis } \\
\text { - Kehadiran jenis atraksi pariwisata baru yang dibawa oleh } \\
\text { ekspatriat hanya menjadi atribut baru, dan tidak } \\
\text { menggantikan atraksi yang lama yang sudah menjadi } \\
\text { identitas Ubud } \\
\text { - Ubud masih menjadi salah satu daya tarik pariwisata Bali } \\
\text { dan masih berpotensi untuk terus dikembangkan ke arah } \\
\text { yang positif } \\
\text { - Ubud masih bisa bersaing dengan berbagai destinasi } \\
\text { wisata lain di Bali maupun di Indonesia }\end{array}$ \\
\hline
\end{tabular}

\section{Penutup}

Mengadaptasi model Tourism Area Life Cycle, saat ini perkembangan pariwisata Ubud berada pada tahap konsolidasi dan interaksi modal (modal ekonomi, modal budaya, modal simbolik dan modal sosial) di antara ekspatriat, masyarakat dan elit menjadi semakin erat dan lebih kompleks. Pada seluruh proses ini, secara umum simbiosis mutualisme lebih dominan, meskipun demikian dalam beberapa kasus masih terjadi praktek marginalisasi dan hegemoni yang diukur berdasarkan kepemilikan atas modal, terutama pada dimensi sosial, ekonomi dan lingkungan di antara ekspatriat, masyarakat dan para elit Ubud. Untuk itu, agar bisa maju dan bersaing di dunia internasional diperlukan kesadaran bersama di kalangan masyarakat dan elit lokal untuk bahu-membahu membangun dan meningkatkan kualitas dan kuantitas modal mereka. 


\section{Ucapan Terima Kasih}

Penelitian ini dibiayai dari DIPA PNBP Universitas Udayana TA-2020, kami menyampaikan terima kasih setinggi-tingginya kepada LPPM Universitas Udayana, Kementerian Riset, Teknologi, dan Pendidikan Tinggi Republik Indonesia.

\section{Daftar Pustaka}

Armstrong, John, 1976. 'Mobilized and Proletarian Diasporas' dalam The American Political Science ReviewVol. 70 No. 2, hal. 394.

Bourdieu, Pierre. 2007. Languange and Symbolic Power. Polity Press: Malden.

Butler, Kim, 2001. 'Defining Diaspora, Refining a Discourse' dalam Diaspora. Vol.10. No. 2, hal. 189.

Butler, R.W. 1980.The concept of tourism area cycle of evolution: implications for management of resources. Canadian Geographer 24 (1), 5-12.

Cohen, Robin. 1997. Global Diasporas: An Introduction. Routledge. London: UCL Press and Seattle: University of Washington Press.

Dantes, Nyoman. 2012. Metode Penelitian. Yogyakarta: Penerbit Andi Dufoix, Stèphane. 2008. Diaspora. USA: University California Press.

Green, Paul. 2016. 'Biomedicine and 'Risky' Retirement Destinations: Older Western Residents in Ubud, Bali' dalam Journal of Medical Anthropology. Vol. 35, Issue. 2, 2016 hal 147-160, DOI: 10.1080/01459740.2015.1088846.

Homans, G. C. 1958. 'Social behavior As Exchange', dalam American Journal of Sociology, 63: 597-606.

Levitt, T. 1965. Exploit the Product Life Cycle. Harvard Business Review, 43, 81-94.

MacRae, Graeme. 2014. Budaya Tembok : The New Ubud. dalam http://ubudnowand then.com/Budaya-Tembok-The-New-Ubud// dikunjungi tanggal 5 Januari 2016 pukul 11.00 Wita.

MacRae, Graeme. S. 1997. Economy, Ritual and History in a Balinese Tourist Town. Thesis / Desertasi Doktor. New Zealand: University of Auckland.

Narottama, Nararya. 2014. International Diaspora And Tourism : Recent Development Of European Diaspora In Ubud, Bali (An Exploratory Research). Proceeding International Tourism Conference. 
Ningtyas, Eka. 2016. Dari Ekspatriat Barat Sampai Hippies : Pariwisata Bali 1920-1970an. Tesis. S2 Ilmu Sejarah Universitas Gajah Mada : Yogyakarta.

Picard, Michel. 1992. Bali: Tourisme culturel et culturel touristique, Paris: Editions l'Harmettan.

Pitanatri, Putu Diah Sastri dan Putra, I Nyoman Darma, 2016. Wisata Kuliner: Atribut Baru Destinasi Ubud. Denpasar: Jagat Press.

Siregar, Mangihut. 2016. 'Teori « Gado-gado » Pierre-Felix Bourdieu'. Laporan Riset, dalam Jurnal Studi Kultural Vol. 1 No. 2 79-82.

Sudipa, I Nyoman. 2014. Paradox Of Poverty In Village Ubud. E-Journal of Cultural Studies, Agustus. ISSN 2338-2449.

Sukawati, Tjokorda Oka Artha Ardhana. 2008. Perubahan Spasial Desa Adat Ubud Kabupaten Gianyar Dalam Era Globalisasi. Disertasi. Pascasarjana Universitas Udayana.

\section{Profil Penulis}

Nararya Narottama merupakan seorang dosen tetap di Fakultas Pariwisata, Universitas Udayana. Sebelum terjun ke dunia akademis, ia pernah bekerja di beberapa hotel internasional di Bali, Amerika dan Kanada. Pada tahun 2012 ia menyelesaikan pendidikan S2 di Université Paris 1 Pantheon - Sorbonne, Paris, Perancis, dan tahun 2019 lalu berhasil meraih gelar Doktor bidang pariwisata di Universitas Udayana. Selain aktif mengajar, saat ini ia telah menerbitkan beberapa buah buku, prosiding dan menulis di jurnal ilmiah pada lingkup wisata spiritual, sosial-budaya, ekpatriasi dan migrasi internasional.

Natasha Erinda Putri Moniaga adalah salah seorang dosen di Fakultas Pariwisata, Universitas Udayana. Baru memasuki dunia akademis selama setahun belakangan dan sejauh ini sedang berjuang menyelesaikan pendidikan S3-nya. Fokus dan ketertarikan dalam penelitian bidang ilmu pariwisata adalah psikologi, semiotika visual, bahasa, dan content marketing. Di waktu luangnya gemar menulis fiksi ilmiah, fotografi, bertualang, serta meracik berbagai jenis teh. 